\title{
Revisiting British royalty myths in Alan Bennett's The Uncommon Reader
}

\author{
Mihaela Culea \\ Vasile Alecsandri University of Bacău, Romania
}

\begin{abstract}
Motto: "I shall be telling this with a sigh Somewhere ages and ages hence: Two roads diverged in a wood, and I I took the one less travelled by, And that has made all the difference"
\end{abstract}

\section{Introduction}

A number of English writers have started to criticize the monarchy in line with public anti-monarchist views which are mainly stimulated by campaign group Republic. $^{2}$ Among them, Sue Townsend (1946 - ) is both comical and subtly ironic in her novels The Queen and I (1992), Number Ten (2002) or Queen Camilla (2006). In The Uncommon Reader (2006/2008), the critical voice of another English writer, Alan Bennett (1934 - ), is milder and more sympathetic; yet, underneath the apparently humorous attitude concerning the British monarchy, he also tackles some significant concerns or complaints of the British subjects concerning their sovereign.

The British monarchy is one of the oldest and most reputed monarchies in Europe, and it is often associated with ideas of high status, privilege, and power. However, real executive power of the monarchy in Great Britain has gradually been removed and many critics consider that the monarch has retained only a symbolic role nowadays (Golby \& Purdue 1988, Davies 2000, Panton 2011, Oakland 2011). Yet, the monarch still has formal constitutional roles and is head of state, head of the

\footnotetext{
${ }^{1}$ The last stanza of Robert Frost's poem "The Road Not Taken" (1916), retrieved from http://www.poets.org/viewmedia.php/prmMID/15717, September 42013.

${ }^{2}$ See http://www.republic.org.uk/What\%20we\%20want/index.php for details. Retrieved October 212013.
} 
executive, judiciary and the legislature, supreme governor of the Church of England and commander-in-chief of the armed forces. In effect, the correct constitutional title of the British Parliament is the "Queen-in-Parliament" which means that state and government affairs are carried out in the name of the monarch by the politicians and officials of the system (Oakland 2011: 94).

The limits to royal power include the following aspects: the monarch must be politically neutral, and it is said that the head of state is expected to reign but not rule. The monarch cannot make laws, impose taxes, spend public money or act without consent of the Parliament. In fact, he/she acts on the advice of government ministers, so Britain is now governed by Her Majesty's Government in the name of the Queen.

Nonetheless, Her Majesty Queen Elizabeth II (1952 - ) still performs a series of practical roles and duties, such as the opening and dissolving of Parliament, giving the royal assent to bills which have been passed by both Houses of Parliament, appointing government ministers and public officials, granting honours, leading meetings of the Privy Council, and fulfilling international duties as head of state. For instance, Her Majesty acts as host to the heads of state of the Commonwealth and other countries when they visit Britain, and receives other notable visitors from overseas. During the past sixty years, the Queen and Prince Philip have also made frequent visits to other countries outside the Commonwealth at the invitation of foreign heads of state. Since her coronation, the Queen has also visited nearly every county in Britain, observing new developments and achievements in industry, agriculture, education, the arts, medicine and sports and many other aspects of national life.

Alan Bennett's novella shows that reading gradually humanizes the Queen, as the author himself stated. Thus, before taking up the reading passion, "she had never really imagined what it was like to be one of her subjects. And now she does. Books really humanize her". ${ }^{3}$ Reading leads to self-discovery and assists the Queen in discovering latent potentialities for sympathy, kind-heartedness and humaneness. ${ }^{4}$ Thus, reading broadens her view on life and expands her knowledge

\footnotetext{
3 http://www.npr.org/templates/story/story.php?storyId=14470364, retrieved October 1 2013.

${ }^{4}$ For a detailed analysis of the delights of reading, its transformative power as well as reading and writing as processes of self-discovery see Culea, M. (2013). Humanizing the Queen: Reading as Self-discovery and Writing as Redemption in Alan Bennett's The
} 
of human nature, its weaknesses and capacities. She starts with texts that do not require much intellectual effort, but after her 'apprenticeship' in Norman Seakins' company ends, she is ready to explore a wide range of texts written by English or international authors from different historical periods, such as Laurence Sterne, Henry Fielding, Jane Austen, Charles Dickens, the Brönte sisters, Joseph Conrad, Winifred Holtby, Anthony Trollope, Honoré de Balzac, Ivan Turgenev, Henry James, Sylvia Plath, Marcel Proust, Virginia Woolf, Alice Munro, Samuel Beckett, Vladimir Nabokov, Philip Roth, Gerard Genet, or the memoirs of American actress Lauren Bacall.

\section{Methods, aims and scope}

Bennett imagines a Queen of Great Britain who grows fond of reading and many reviews of the book ${ }^{5}$ discuss the Queen's discovery of the wonderful and magic world of literature, the pleasures of reading and the many positive effects of reading on people in general, and all the more on the Queen of Great Britain. For instance, the Guardian journalist Edward Marriott comments that the novella is "a gloriously entertaining comic narrative, but it is also much more: a deadly serious manifesto for the potential of reading to change lives, for its ability to broaden horizons, to imagine oneself in others' shoes, and to enable one (...) to break out from the constraints of upbringing, class and education and lead the life you've always wanted. And, Bennett ponders, who might need that more than the Queen?"6

For Bennett's Queen, reading is not only diverting and enriching, but also transformative. Just as one book leads to another, reading eventually leads to writing, the writing of her own life which, in turn, proves to be liberatory and

Uncommon Reader. Rupkatha Journal on Interdisciplinary Studies in Humanities, Vol. V, No. 3, 91-108.

${ }^{5}$ In fact, there are no critical investigations of the novel for the moment, except for a number of book reviews such as those which can be found at the following links: http://theuncommonreader.tumblr.com/post/16685097901/the-uncommon-reader-by-alanbennett, http://www.guardian.co.uk/books/2012/may/29/uncommon-reader-alan-bennettreview, http://www.nytimes.com/2007/10/30/books/30kaku.html, retrieved September 14 2013.

${ }^{6}$ Marriott, E. (2007). What One Thinks of Henry James. The Guardian. Retrieved from http://www.theguardian.com/books/2007/sep/30/fiction, October 192013. 
redemptive. Probably the Queen felt that writing could be doubly beneficial. On the one hand, it would help her open up to her subjects and thus remove the social, emotional and communicational gaps which have often constituted a matter of public discontentment. On the other hand, writing could coincide with gaining knowledge of her private self, a dimension of her personality which has always been covered, concealed, obscured by the many official duties which have always taken a primary role. The exploration of selfhood is initiated by reading and then augmented by writing, a plan that seeks to recuperate the time spent only with exercising state duties at the expense of private experience and personal agency. This route is hard and the Queen's attitude is somehow unenthusiastic at first, but reading gradually changes her life and, by the end of the book, it does alter it, and that of the state, quite dramatically.

My contention is that Bennett's book may indeed be inspiring, imaginative and humorous from many viewpoints, but it is also deeply rooted in contemporary issues concerning the British monarchy, and its critical views should also be pointed out. Reading turns out to be a suitable occasion for the literary reflection of the public censure of the monarchy.

The research methodology of the article involves a cultural and historical approach that rests on the empirical literary examination of the novel. Firstly, the article shows that the narrative is a catalyst for subtle criticism of the British monarchy. Bennett does not necessarily target the monarch as a person, namely Queen Elizabeth II who is now sitting on the throne; on the contrary, it is the depersonalization and exaggerated institutionalization of the person as such that represent the target of his satire. The function of head of state has deprived her of personality or individuality to the extent of making her impersonal. Additionally, the novel may also indicate that the monarchy in Britain can no longer be a stable, fixed, immutable institution and that tiny fractures have become visible in the structure of the oldest lay institution in Britain. It mildly signals that the antiquated institution of monarchy, as a concept and as a symbol, can no longer handle the challenges of contemporary life. Leonard (1997: 2) shows that faith in British institutions has decreased, so "barely $30 \%$ think Britain will have a monarchy in 50 years' time".

Secondly, underneath the central theme that depicts reading as the new hobby of the British monarch, the novel also deals with issues connected to the world of politics, social class structures, or economic difficulties. For instance, the 
monarchy is said to have perpetuated an unfair social system, while economic troubles have affected only a part of the British population. Politically, the monarch's power has, over time, greatly diminished, with the result that now the Queen retains a more symbolical and ceremonial function. Still, the Queen's personality stands out as strong, witty, dutiful, firm, and sharp and Bennett resolves to portray her quite affectionately, emphasising the many qualities which, in fact, have enabled her to secure her crown for so many years. On the other hand, the group of political advisers is portrayed sarcastically as a body which does not always take the right decisions, and as an unscrupulous, deceptive and dangerous class.

By representing concerns related to the British monarchy, the novel also inquires into a set of values commonly attributed to the monarchy, its principles and attitudes, as well as the political prerogatives of the monarch as compared to those of the Prime Minister. Consequently, it refers to the Queen's highly praised sense of duty, the continuity and stability of the monarchy, its exclusiveness in point of rights, its distinction, the set of socio-economic privileges which creates a social and affective gap between the royalty and the common people, its conventionality and traditionalism, as well as its demoted political status or the issues of regionalism and nationalism. However, the article intends to investigate the way in which Bennett revisits or re-evaluates some of the myths ${ }^{7}$ of royalty. By using reading as a vehicle, Bennett subtly reconsiders a set of common values or principles associated with the British monarchy, bringing to light a new conception of the monarchy and its relation to the British people.

The article further discusses the ways in which some common values or practices defining the British monarchy, and particularly Queen Elizabeth II, are influenced and changed by the Queen's new passion, reading, and the effects produced by this transformation upon the monarch as a person and upon the institution she embodies.

\footnotetext{
${ }^{7}$ By myth we understand something people wrongly believe to be true.
} 


\section{Reading and the reconsideration of British royalty myths}

\subsection{The change of duties}

The Queen's new enthusiasm for reading destroys many of the common myths about her personality or the institution she represents and turns them upside down. For example, the Queen is famous for her ardent sense of duty. Although real executive power is almost absent nowadays, the Queen diligently reads all important governmental papers, so she has sound knowledge of what is happening in central areas of the state policy. She sees all Cabinet papers and the records of Cabinet and Cabinet Committee meetings, she receives important Foreign Office telegrams and a daily summary of events in Parliament. She has the right to be informed on all aspects of national life, so her knowledge of current situations and trends is incredibly up to date, often to the embarrassment of her Prime Ministers. Winston Churchill, who had served four monarchs, was impressed and delighted by her knowledge and wit. One of her most dutiful activities is her inspection of the two red boxes sent to her from Parliament every day, which contain official documents. She likes being informed and she feels it is her duty to do so; in fact, she was inculcated as a teenager, and later when she became Queen, that it was her duty to read and try to understand as much as she could about her government (Davies 2000: 240-1).

However, the novel quickly deconstructs this myth as a consequence of her growing fondness for reading. Excessively dutiful before reading took control of her, the Queen soon starts to disregard her duties, and resorts to lying so that she could get on with her books. With reading taking up most of her time, the Queen in the novel does her red boxes less doggedly, and her public duties also begin to suffer: "she laid foundation stones with less élan and what few ships there were to launch she sent down the slipway with no more ceremony than a toy boat on a pond, her book always waiting" (45-6).

Her private secretary believes that her reading interferes in her duty and prevents her from "staying focused" (28), but the Queen responds to criticism by recalling her long-standing performance of duty all through her life, which has always occupied a central role. So, now, after so many years on the throne, she thinks she "is allowed the occasional glance to the boundary" (29). Reading, the Queen shows, is not popular in royal circles, because it is thought to be idle, passive and distracting. 
Reading starts to meddle in the Queen's most important official duties. For instance, the state opening of Parliament is now tiresome and her passion for reading makes her share this obligation with reading. In a rather comical instance, we see the Queen both "reading and waving" (32) at the same time, cunningly hiding her book from the public, "the trick being to keep the book below the level of the window and to keep focused on it and not on the crowds" (32). Hence, Bennett ironically insinuates that the Queen starts neglecting her duties and treats her subjects unresponsively. It might be assumed that, although reading is supposed to assist her in acquiring knowledge of human nature, it seems to lead her on the wrong path, so she apparently goes astray from her subjects even more. Now, her obligations become awfully "tedious" (60) and dreadful.

The Queen's reading becomes a real nuisance for her advisers. Her growing neglect of her duties makes her tour to the Commonwealth countries nothing but a weary task. The tour to Canada turns into a disaster after her books are intentionally misdirected by her private secretary, Sir Kevin Scatchard. She no longer fulfils her duties enthusiastically and completely, and she even leaves some of her official engagements aside. The Queen was "bored, uncooperative and glum", "bad-tempered and difficult" (66), because now she realizes that her repeated visits there brought nothing new to her experience of human nature, while books always unfold a novel, unique, and exciting universe.

\subsection{Emotional and social distance}

A common critique of the monarchy is that most members of the royal family maintain a sense of distance and detachment from ordinary citizens, and the Queen in particular has often been criticized for this. Leading an exclusive life from a social and economic perspective, the monarchy has remained ignorant of the life of its ordinary subjects. However, in the novel, the much-condemned distance of the monarch from her subjects is gradually reduced due to the world of books. Reading eventually helps her improve her relation with the British people. Getting closer to her subjects, with people gifting and being gifted books during royal visits, the Queen becomes burdensome for her equerries, who comment that it is getting harder and harder to manage her. Meetings turn into some sort of reading clubs, with the Queen and her subjects exchanging books: "nowadays they fetch along books they're reading, or (...) even writing, and if you're unlucky enough to be in 
attendance you practically need a trolley" (42). Literary discussions on the work of English writers like Virginia Woolf or Charles Dickens finally provide the ground for the "meeting of minds" (43). However, most people are not interested in the classics of English literature and prefer contemporary bestselling authors like Andy McNab, J.K. Rowling or Joanna Trollope (43). This might show that people are quite disinterested in their past, and that their pragmatism determines them to focus on the present, while the Queen seems to live in the past, somehow disconnected from contemporary concerns and tastes.

The difference of social status and position widens the affective gap which has taken shape between the monarch and her subjects, so that no personal communication or communion between the two parties can exist. She was aware that she "inhibited" (17) people in general and her servants in particular. Though they worked with the Queen, they never felt at ease in her presence nor did they behave like themselves. This affective and communicational barrier distances the Queen from her people. For instance, the Queen's invariable self-control in public has often been interpreted as lack of compassion in her relation with her subjects.

Her language is also illustrative of the communicational distance from her subjects, as well as from her own self. The Queen's English, or Received Pronunciation, is conventional, standard British English which is considered correct by most people. The Queen constantly uses the indefinite, generic pronoun "one" as a substitute for the first person pronoun. An instance of British usage, this linguistic form generalizes the statement and adds the nuance of indefiniteness. Thus, it shows that the Queen is unable to personalize her own discourse and thus, her own life: "Though it is true one is eighty and this is a sort of birthday party. But quite what there is to celebrate I'm not sure. I suppose one of the few things to be said for it is that one has at least achieved an age at which one can die without people being shocked" (110; my emphasis). This happens all the more now that she realizes that her life has not been "much of a boast" (94).

The communicational obstacle between the Queen and her subjects is also obvious during her travels around the Commonwealth, when people are generally shy, "tongue-tied" (52), even speechless. But the situation reverses when the Queen arranges to meet a group of writers. Now she is the one who feels unable to speak, quite numbed particularly because there is such a gap between the interests, abilities, status and position of both parties involved. Unable to freely communicate with the writers she was so eager to meet, the Queen resumed the use 
of clichés. Her proverbial self-control, censorship of language and emotions as well as her over-formality also prevent her from being closer to the writers she meets and she cannot express her feelings openly because "fifty years of composure and self-possession plus half a century of understatement stood in the way. Hard put for conversation, she found herself falling back on some of her stock stand-bys" (52). The same happens when she meets her people, the monarch and her people constituting two groups almost living in different worlds because of the huge differences generated by origin, status, and wealth

However, Norman, her literary assistant and a self-taught young man, does not fit in the group of people who are discomfited by the Queen's presence. In her company, he "was himself and seemed incapable of being anything else" (17). Very rare though this was, the Queen probably felt Norman was one of those few people whom she could closely communicate with. She anticipates there is room for human connection irrespective of social rank, a fact which was very uncommon for her routine human interactions. Reading will soon show her that human connection will turn out to be something which transcends social barriers, a type of equality she actually was yearning for.

The Queen's inflexibility and coldness have sometimes been criticized publicly, especially on the occasion of sad events like Princess Diana's death (Childs \& Storry 1999: 345). Bennett offers a different response to this common allegation, presenting her emotional rigidity as a misunderstood part of her character. The Queen feels akin to Shakespeare's Cordelia who simply could not verbalize or express her thoughts and feelings easily, but this did not mean that she lacked them. Quoting Cordelia's "I cannot heave my heart into my mouth" (81), she explains that, even though her people would like her to communicate her feelings vocally, this was not part of her nature.

The monarch is often regarded as a symbol of the continuity and stability of British identity. However, this sense of stability has also been accompanied by the fact that the monarch has never been allowed to feel. Being a mere state machine, it has been thought that the absence of sensitivity towards her family or her people in general could help the monarch keep focused on state affairs. This is because emotion of any sort could impair the monarch's "guiding principle" (71). The firmness of her character also rests on lack of sentiment, but the text suggests that the public appreciation of the monarch as a symbol of continuity is an exaggerated notion because the permanence of the institution was upheld to the detriment of 
human affection and closeness. Political power also encourages dehumanization. It is the world of books that helps her realize she was not allowed to be human and humane, especially in matters related to allowing oneself to feel and act accordingly. If the condition of being a writer "didn't excuse one from being a human being", "being Queen does. I have to seem like a human being all the time, but I seldom have to be one. I have people to do that for me" (73). Her very humanity reduced to nothing, the Queen can only serve the state and be employed for that reason.

Hence, in this case, political continuity is totally opposite to human attachment and the monarch is the only enduring element of this machine, for "they left but she went on" (71). The image of an insensitive monarch created by her political entourage results from the fact that "sudden absences and abrupt departures had always been a feature of her life. She was seldom told (...) when someone was ill; distress and even fellow feeling something that being Queen entitled her to be without, or so her courtiers thought" (71; my emphasis). The monarchy's many titles, ranks and privileges have also distanced the royalty from the common people. The outcome of the political and social privileges attached to royalty was that the Queen was ironically entitled to be devoid of human feeling, too.

The new contact with the world of books determines the Queen to introduce reading in her relationship with her subjects, and she regrets that the state opening of Parliament is the single occasion when she addresses her people and reads to them aloud. Still, even this unique chance is tedious, formal and impersonal, and the Queen is forced to talk about things she does not perform but her government does. She feels that the conventionality of the situation and the lack of personal involvement distort and even degrade the act of reading which, now she understands, is a participative, subjective process. Similarly, just as any official written text is, her speech is devoid of emotional imprint or markers of individual style: "it was so barbarously phrased and wholly devoid of style or interest that she felt it demeaned the very act of reading itself" (33).

To her attendants' surprise, she starts taking some decisions which were not really common for her. On a regular basis, the Queen gets involved in honorary ceremonies in which people are conferred titles and ranks for personal merit or some kind of service rendered to the country. But now she decides that Norman Seakins, the servant working in the kitchen, should be promoted because he certainly seemed "a young man of some intelligence" (15). From her first visit to 
the travelling library, Norman amazes the Queen with his knowledge of books, his familiarity with literature obviously exceeding hers. Though the relationship seems to place the Queen at a disadvantage since a servant seems to be more learned than the head of state, she recognizes his merit and believes he deserves a better position in the Palace. Promoted to the job of page, he is supposed to assist the Queen with her readings. Of course, Norman was by no means a widely informed man, but rather a "self-taught" (16) reader whose book choices depended on whether the writer was gay $^{8}$ or not. The selection might thus seem limiting at first but, gradually, as he turns effectively into the Queen's amanuensis, he advises the Queen on a long and varied list of books. This variety will eventually expand her knowledge of humanity and human nature.

\subsection{The British monarchy as a conventional, traditional and temporally misplaced institution}

Conventionality is another well-known feature of the Queen who always conforms to traditional practices in her official activities. Similarly, British traditionalism has been regarded both as a national asset and a setback to modernization. The monarchy's failure to adapt to modern times has often been criticized (Morgan 2000: 100). Britain's association with ideas of traditionalism and conventionality partly derives from the age-old existence of the monarchy, as well. Among a set of concepts and attributes commonly associated with Britishness, the monarchy is also held responsible for Britain's backward-looking vision in most areas of human life.

Consequently, it is believed that Britain definitely has a rich past, whereas its future is indistinct. David Mercer, Head of Design at BT, former British Telecom, observed that the name "British" was sometimes connected in some parts of the world with something “ 'of the past', 'colonial', not about innovation, not about high technology, or the future or moving ahead" (Storey 2010: 14).

\footnotetext{
${ }^{8}$ A troubling issue for Bennett himself, gayness may be considered a secondary theme of the narrative, satirically reflecting common biased views concerning homosexuality. Also see http://www.theguardian.com/stage/2009/nov/08/alan-bennett-habit-of-art, retrieved August 252013.
} 
In the novel, the Queen's new hobby subtly repudiates conventionality of behaviour, attitude and thinking. The Queen discovers the palace library, which turns out to be more like a political space or a meeting place rather than one intended for reading because the royals seldom read here: "ultimatums were delivered here, lines drawn, prayer books compiled and marriages decided upon" (18). Books are locked in huge bookcases; out of reach, they are unable to perform the function they were destined for, namely perusal by a reader. The London Library is another reading space which is unfamiliar to the Queen, though she is its patron. This institution as such - as well as all institutions associated with the Queen - is also seen as obsolete and antique, or no longer connected with the present, "confined to the past" (19). Understanding the unfitness of such spaces for her passion, the Queen prefers hidden places in the palace where she can secretly indulge in her new activity.

Royal visits to the Commonwealth countries represent another characteristic feature of the British monarchy nowadays. Bennett critically discusses the uselessness of the famous royal tours mainly because of their formality, conventionality and lack of genuine human contact between the monarch and her people. The carefully planned engagements and the regular stock conversations make no significant contribution to her knowledge of people's needs, nor do they foster human closeness. The routine small talk topics like traffic and parking problems, distance travelled, place of origin, length of service (41) impede personalization and maintain the distance which exists between the monarch and her subjects. The verbal exchanges do not represent instances of efficient communication; people speak to each other but they do not reach each other's hearts. However, it is reading that gets them closer because it denies ready, predictable answers, thus paving the way for real communication. Now that the Queen discovers the wonderful world of books, discussions are longer and become warmer, and the meetings represent the suitable occasion to share each other's aesthetic interests, thoughts, and emotions. Finally, for her people, the most anticipated meetings of their lives are no longer dry, cold, and terse. In former times, people regretted the conventionalism of the conversation, but now they feel ashamed they are unable to respond adequately to the Queen's interest in their readings, simply because people hardly read: "the audience got longer and more ragged, with a growing number of her loving subjects going away regretting that they had not performed well and feeling, too, that the monarch had somehow bowled them a googly" (41). Again, we notice here that Bennett alludes to the 
difficult socio-economic condition of many of the British subjects. The fact that they often sell the gifted books online shows that poverty is a much more critical issue for the ordinary people.

This leads to another common negative appraisal of the British monarchy. Because of its long existence, conventionality and traditionalism, the monarchy has often been viewed as anachronous and unadapted to the present times. However, the Queen's growing interest in history does not necessarily mean that she is stuck in the past and thus disconnected from the troubles of the present. What Bennett probably wants to suggest is quite the opposite, namely that knowledge of the past helps us understand the present and so it prevents people from making the same mistakes again. The excessive pragmatism of her advisers involves neglect of past times and thus impedes progress by disregarding the roots of the nation's identity. Sir Kevin is careless about the lessons that can be drawn from the past. Instead of looking for the causes of the present turmoil in the past events and actions, he believes that the present reflects a struggle for survival which has nothing to do with the past. Hence, Bennett suggests that adherence to tradition may not necessarily be wrong or counterproductive, but quite instructive and useful.

The Queen herself is regarded by her private secretary, Sir Kevin Scatchard, a New Zealander, as a vestige of the past. In his view, the old regulations related to the Crown are outdated, difficult to approach, distant from the people and so, perhaps quite undemocratic. For him, the British monarchy resembles Charles Dickens' Miss Havisham, both being stuck in the past, while his mission is to make the monarchy "more accessible" (27). For the moment, the monarchy evoked Miss Havisham's house, with its "cobwebbed chandeliers, the mice-infested cake and Sir Kevin as Pip tearing down the rotting curtains to let in the light" (26-7). A graduate of business, he plans to invigorate and modernize the monarchy. If most people were obsessed with their origin, name or status, the Queen cares nothing for all of this. To her, “everybody's name was immaterial, as indeed everything else, their clothes, their voice, their class" (28). In a class-ridden society, she was a true democrat, "perhaps the only one in the country" (28). On the other hand, Sir Kevin upholds class differences and connects the maintenance of hierarchy with reading, too. In his view, reading is an exclusionary activity, it widens the gap between the royals and the common people who do not read much. Like art in general, reading is an "elitist" (27) practice, it does not correspond to the hard daily life of the ordinary people. Here, Bennett alludes not only to the financial crisis which has affected the cultural life of the nation too, but also to the deterioration of artistic 
tastes of the British population. However, as we have pointed out, reading will eventually get the monarch and her people closer.

\subsection{Art as remoteness from public interests and concerns}

The Queen's growing interest in arts is perceived as detrimental to the socioeconomic areas which are of central concern for her government. In the novel, art and commerce meet on conflicting grounds and there is a deep chasm between arts and business or manufacturing. As her Prime Minister constantly reminds her, business issues have a major role for the population because they generate workplaces, profit, and financial progress. Fascinated with the world of books, the Queen grows quite indifferent to business, convinced that literature "may be relevant" (38) and pays no attention to her politicians' insistence on industry, which is in sharp decline and is thus all the more significant for her subjects.

From her Prime Minister's viewpoint, reading distances the Queen even more from her people. This is because reading shapes the image of a monarch who is unconcerned with the real problems of the population and plunges into a dream world of fiction. Still, the Queen thinks that the inclusion of reading in her Christmas broadcast would add a sense of familiarity and closeness to the relationship with her subjects, but again her private secretary suggests that the effect would be contrary to her expectations. It would show the monarch as being anachronous or ill-suited to contemporary times in which social, economic and political matters count. Poetry seems useless because people need to hear of something useful for their daily lives. Moreover, the poem she intends to read would send a politically inadequate message, namely that "fate is something to which we are all subject" (57), and thus it would mean that the monarchy and its government no longer assume responsibility for political action, or that the political situation is no longer manageable. Sir Kevin feels it is the duty of politicians to constantly nourish the public feeling of order, optimism, constructive action, and trust. Thus, a pragmatic monarchy would be better suited because it would uphold this image of monarchy as an institution which is actively engaged in securing the welfare of its people. Some appropriate topics for her media appearances could thus be related to contemporary issues or events like her visit to South Africa, a fact which could strengthen the Commonwealth, especially since a growing 
number of British people oppose the maintenance of this non-political partnership, and see it as a moribund association with no concrete and practical roles.

In the end, the Queen does insert reading in her annual Christmas message, choosing the opening paragraph of Charles Dickens' A Tale of Two Cities: "it was the best of times. It was the worst of times" (58). This excerpt sends a more acceptable political message because it diverts people's attention from present troubles. It could also highlight the duality of human nature and life in general, showing that misery and happiness, bad and good coexist, and so the British population could accept present-day distressing circumstances, be they social, economic, or political, more easily.

\subsection{Political roles of the monarch and governmental concerns}

The British monarch still has the right to choose and appoint the Prime Minister. In fact, as Head of State, the Queen often communicates with the Prime Minister, with whom she has a weekly audience when she is in London. Bennett suggests that the importance attached to the famous Tuesday meetings is a myth. The mass media falsely represent these meetings as consultative and highly productive from a political viewpoint, thus upholding a view of monarchy as an institution which still has a say in politics. In reality, the longer they are in office, the more powerful the Prime Ministers grow. As decision makers, in time, their position is enhanced, whereas the Queen comes to maintain a merely decorative role and her opinion barely matters: "the truth being the longer they were in office the less the prime ministers listened and the more they talked, the Queen nodding assent though not always agreement" (55).

Bennett also deconstructs a common myth about the monarch as a wise and experienced political agent. Taking over the reins of power, the Prime Ministers turn these meetings from political consultations into a form of spectacle. Bennett makes use of words specific to dramatic representations, thus picturing these meetings as a theatrical show in which the parties involved turn into actors. Politically dominated, the Queen maintains the show from the position of audience rather than that of a stage director. It is a type of performance in which Prime Ministers lessen and belittle the political roles of the monarch while increasing their own power. A merely imposed ritual, it is a "show that was required, a show of interest, a show of concern" (55) put on only with the purpose of displaying the 
Prime Minister's political qualities. In order to show the reversal of power roles, Bennett also employs educational language depicting the Queen as a student and the Prime Minister having assumed the position of an experienced teacher. The text suggests that the Prime Ministers try to impose their views on the monarch and these meetings have become instructive in style, with particular emphasis on "lecturing mode", ceasing "to require encouragement from the Queen" but treating her "like an audience, listening to her no longer on the agenda" (55).

In the Queen's view, politics is characterised by bloodshed and excrement (117), and she also associates the world of politics with a battlefield, so she confesses: "I have (...) been forced to participate if only passively in decisions I consider illadvised and often shameful" (118). Foster (2005) shows that there is much public discontent with the British government in general, suggesting that a change of Prime Minister or party would not necessarily bring back public confidence and that a radical improvement of the system could be a much better alternative.

The entire royal household is also characterised in terms of a theatrical performance, with the equerries as stage managers, while the Queen plays the leading role. Politics in general turns into a game in which masks are worn and acting becomes the key paradigm. Though she does act as the central actress in the play, she is not the stage manager herself, so it is clear that she is under the strict control of her advisers and ministers. In addition to this, the Queen is treated more like an object or an instrument in the same state machine. The entire institution is so much ritualized that the official procedures as such count more than the Queen herself. Her staff no longer perceive her as a human being even in some of the more private situations. In her depersonalized condition, she feels that travelling from one residence to another "was a ritual of departure and arrival in which she was just another piece of luggage; the most important piece, there was no disputing that, but luggage nevertheless" (77).

The government insists on pragmatic mindsets and actions for political ends. Her private secretary comes up with the idea that she should use reading as a political instrument which could boost the monarchy's popularity by apparently connecting her reading "to some larger purpose - the literacy of the nation as a whole, for instance, the improvement of reading standards among the young ..." (45). Sir Kevin also believes that, by informing her people of her literary tastes in a press release, Her Majesty could get closer to her people, diminish social differences, 
and look more modern. The Queen's refusal shows that she wants to keep reading as an enriching, pleasurable act which should not be used for political purposes.

A delicate subject of much concern for most British people is the issue of regionalism, separatism and nationalism connected to the four regions of the kingdom. In the twentieth century, the notion of Britishness as a political and identity construct intimately binding the four nations was destabilized because of some major political or cultural phenomena: decolonization and the loss of the Empire, the succeeding immigration flows or regionalism. The contemporary British society is a multinational, multicultural and multi-ethnic community (Oakland 2011: 56). Therefore, the notion of Britishness has taken on a new meaning (Bassnett 2001: 18). ${ }^{9}$ Public adherence to a common set of characteristics defining all people in Great Britain has thus become weaker, and sociological or anthropological studies such as that conducted by social anthropologist Kate Fox $(2004)^{10}$ have restricted the focus of investigation to the defining features of national character in each of the four British regions.

In the novel, Sir Kevin takes into account the ethnic diversity in Great Britain and believes that the Queen's inclusion of ethnic writers from the Commonwealth countries such as Vikram Seth in her reading list could strengthen the national sense of ethnic adhesion. The fostering of ethnic unity sends an advantageous political message and could thus reinforce the notion of multiculturality as a positive phenomenon.

\section{Conclusions}

As we have shown, in Bennett's novella humour blends with political, social, and cultural satire. The situation in which the Queen of Great Britain becomes zealous about reading is certainly humorous. However, this fictional scenario sets the scene for the literary reflection of a number of social, economic and political aspects which represent issues of British public discussion and concern. Whether we refer

\footnotetext{
${ }^{9}$ For further details on Britishness, Englishness and the idea of nationalism also see Wellings, B. (2007). Rump Britain: Englishness and Britishness, 1992 - 2001. National Identities, 9(4), 395-412.

${ }^{10}$ Fox (2004) identifies ten defining features of Englishness, with "social dis-ease" as the central core. Social dis-ease represents the lack of ease, discomfort and incompetence in the field of social interaction.
} 
to the traditional and conservative nature of the monarchy, its exclusive privileges and social distinction, social unfairness, the distance between the monarch and its subjects, the monarchy's aloofness or its disconnectedness from the daily lives of the people, or to political matters of separatism and nationalism, Bennett's vision re-evaluates common ideas about them through the lens of the Queen's new reading habit. It is reading that enables the Queen to expose political scam, social imbalance, and affective barriers.

The author declared that "the best satire comes out of affection", adding that he thinks he is the last monarchist. ${ }^{11}$ Thus, his fictional voice is only mildly reproving, and the image of the Queen is deeply humanized and individualized. Reading is the pretext which assists Bennett in his reinterpretation of the common conceptions about the British monarchy, placing them in a favourable light. Due to reading, the Queen becomes more aware of the political world, she is more eager to erase social differences, and she gets closer to people's hearts. By reading the book, the reader can perhaps imagine the "human side" (80) of the monarch, and the restoration of the monarch's humanity is perhaps one of Bennett's best achievements.

\section{References and notes:}

Bassnett, S. (2001). Rethinking the Victorian Age. European Studies, 16, 15-24.

Bennett, A. (2008). The Uncommon Reader. London: Faber and Faber Ltd, Profile Books Ltd.

Childs, P. \& Storry, M. (1999) (eds.). Encyclopaedia of Contemporary British Culture. London

and New York: Routledge.

Culea, M. (2013). Humanizing the Queen: Reading as Self-discovery and Writing as Redemption in

Alan Bennett's The Uncommon Reader. Rupkatha Journal on Interdisciplinary Studies in Humanities, Vol. V, No. 3, 91-108.

Davies, N. (2000). Elizabeth: Behind Palace Doors. Edinburgh: Mainstream Publishing Projects.

Foster, C. (2005). British Government in Crisis or The Third English Revolution. Oxford and Portland, Oregon: Hart Publishing.

Fox, C. (2004). Watching the English. The Hidden Rules of English Behaviour. London: Hodder \& Stoughton.

Frost, R. (1916). The Road Not Taken, retrieved from

http://www.poets.org/viewmedia.php/prmMID/15717, September 42013.

Golby, J.M. \& Purdue, A.W. (1988). The Monarchy and the British People.1760 to the Present. London: B.T. Batsford Ltd.

\footnotetext{
${ }^{11}$ http://www.list.co.uk/article/4370-alan-bennett/, retrieved August 232013.
} 
Leonard, M. (1997). Britain ${ }^{T M}$ : Renewing our Identity. London: Demos. Retrieved October 10 2013, from http://www.demos.co.uk/files/britaintm.pdf

Marriott, E. (2007). What One thinks of Henry James. The Guardian. Retrieved October 19 2013, from http://www.theguardian.com/books/2007/sep/30/fiction

Morgan, K. O. (2000). Twentieth-Century Britain: A Very Short Introduction. New York: Oxford University Press Inc.

Oakland, J. (2011). British Civilization: An Introduction. $7^{\text {th }}$ edition. London: Routledge.

Panton, K. J. (2011). Historical Dictionary of British Monarchy. Lanham, Toronto, Plymouth, UK: The Scarecrow Press, Inc.

Storey, J. (2010). Becoming British. Higgins, M., Smith, C. \& Storey, J. (2010) (eds.). The

Cambridge Companion to Modern British Culture. Cambridge, UK: Cambridge U.P, 1225.

Wellings, B. (2007). Rump Britain: Englishness and Britishness, 1992 - 2001. National Identities, 9(4), 395-412.

http://www.republic.org.uk/What\%20we\%20want/index.php for details. Retrieved October 212013

http://www.npr.org/templates/story/story.php?storyId=14470364, retrieved October 12013

http://www.theguardian.com/stage/2009/nov/08/alan-bennett-habit-of-art, retrieved August 252013.

http://theuncommonreader.tumblr.com/post/16685097901/the-uncommon-reader-by-alanbennett, retrieved September 142013

http://www.guardian.co.uk/books/2012/may/29/uncommon-reader-alan-bennett-review, retrieved September 142013

http://www.nytimes.com/2007/10/30/books/30kaku.html, retrieved September 142013

http://www.list.co.uk/article/4370-alan-bennett/, retrieved August 232013 


\section{SUMMARY}

\section{Revisiting British royalty myths in Alan Bennett's The Uncommon Reader}

\section{Mihaela Culea}

\section{Vasile Alecsandri University of Bacău, Romania}

In his novella The Uncommon Reader (2006/2008) English writer Alan Bennett (1934 - ) fictionally depicts the way in which one of the most prestigious institutions of Britishness, Queen Elizabeth II (1952 - ), turns from a highly institutionalized symbol into a real person and a very uncommon reader. The article explores Bennett's fictional reconsideration of common myths connected to the British monarchy, a process which is activated by the Queen's new fondness for reading. The paper develops a possible reinterpretation of these myths, seeking to prove that Bennett's fictional exercise also sparks off the reflection of a number of common public concerns connected to the British monarchy and its position in relation to the social, economic or political life of contemporary Britain.

Keywords: British monarchy, myth, institution, duty, continuity, stability, traditionalism, status, conventionalism, distance 